\title{
DISHARMONISASI PERIODE PEMBERLAKUAN RENCANA INDUK PEMBANGUNAN KEPARIWISATAAN DAERAH DI INDONESIA (IMPLEMENTASI PERATURAN PEMERINTAH NOMOR 50 TAHUN 2011 TENTANG RENCANA INDUK PEMBANGUNAN KEPARIWISATAAN) \\ Disharmonized the Impelementation Period of Regional Tourism \\ Development Plan in Indonesia (The Implementation of Government Regulation Number 50 Year 2011 Concerning Tourism Development Master Plan)
}

\author{
Mohamad Rifan', Hilmi Inaya Fikriya² \\ Peneliti Lembaga Konsultasi dan Bantuan Hukum Rumah Keadilan \\ Jalan Kembang Kertas IV No.09, Jatimulyo, Kec. Lowokwaru, Kota Malang, \\ Jawa Timur \\ 12rauna@gmail.com, hilmiinaya4@gmail.com
}

Diterima: 28 Juni 2020. Disetujui: 2 Desember 2020. Dipublikasikan: 30 Desember 2020

\begin{abstract}
Abstrak
Otonomi Daerah mendatangkan konsekuensi bagi masing-masing daerah untuk mengurus dan menggali potensi di wilayahnya. Lebih dari itu, daerah juga diberi opsi terhadap penggalian dan pengolahan sektor pariwisata yang berpotensi mengoptimasi pembangunan daerah. Komposisi kepariwisataan di Indonesia terdiri atas tingkatan nasional sampai daerah dengan memperhatikan keanekaragaman, keunikan, serta kekhasan budaya dan alam masing-masing daerah. Konsekuensinya, sebagaimana disebutkan Undang-Undang Nomor 10 Tahun 2009 tentang Kepariwisataan Pasal 8, pembangunan kepariwisataan yang dilakukan berdasarkan rencana induk pembangunan kepariwisataan merupakan bagian integral dari Rencana Pembangunan Jangka Panjang Nasional. Oleh karena itu, jangka waktu perencanaan RIPPARPROV dan RIPPARKAB/KOTA juga menyesuaikan dengan periode waktu Rencana Pembangunan Jangka Panjang Daerah Kabupaten/Kota yang tentu saja sama dengan periode waktu Rencana Pembangunan Jangka Panjang Nasional (RPJPN). Akan tetapi faktanya, implementasi UU Kepariwisataan dinilai tidak optimal dikarenakan beberapa Rencana Induk Pariwisata mengalami disharmonisasi pada skala periode pemberlakuan, seperti RIPPAR-Prov Jawa Timur dan Jawa Tengah, atau RIPPARKota Surakarta dan Balikpapan. Melalui metode penelitian yuridis-normatif dan pendekatan peraturan perundang-undangan serta konseptual, peneliti menganalisis konsekuensi disharmonisasi Rencana Induk Pembangunan Pariwisata berdasarkan 3 (tiga) sudut pandang teori hukum yaitu teori sinkronisasi, teori harmonisasi, dan teori pembangunan hukum.
\end{abstract}

Kata Kunci: Harmonisasi, Pembangunan, Rencana Induk Pembangunan Pariwisata. 


\begin{abstract}
Regional autonomy brings consequences for each region to take care of and explore its potentials. Moreover, the region is given options to manage the tourism sector which is potential to optimize the development of the district. The composition of tourism in Indonesia consists of regional up to national levels by concerning the diversities, uniqueness, and peculiarities of its culture and nature. Consequently, as mentioned in Act No. 10 of the year 2009 concerning tourism of article 8 mentioned that tourism development is conducted based on the master plan for tourism development is an integral part of the national long-term development plan. Therefore, the planning duration of RIPPARPROV and RIPPARKAB/KOTA also adjusts to the period of the Regency/city longterm development plan which is the period is same as the national long-term development plan (RPJP). However, the implementation of tourism law is not optimal due to some of the main tourism plans having disharmony on the scale of its validity periods such as RIPPARProv East Java and Central Java, or RIPPAR-Kota Surakarta and Balikpapan. Through the Yuridis-normative research method and the approach of statutory and conceptual regulations, researchers focus on analyzing the consequences of the disharmony of the main tourism plan base on 3 (three) theories of law which are synchronization theory, harmonization theory, and legal development theory.
\end{abstract}

Keywords: harmonization, development, tourism development master plan.

(C) 2020 Direktorat Kajian Strategis

\section{PENDAHULUAN}

Pasal 18 UUD NRI 1945 telah menentukan bahwa negara Indonesia terbagi menjadi daerah-daerah provinsi serta di bawahnya terdapat daerah-daerah kabupaten/kota yang mempunyai pemerintahan daerah sendiri. Ketentuan tersebut menjadi dasar konstitusional terbentuknya pemerintahan daerah yang kemudian dikenal dengan otonomi daerah karena kewenangan yang diberikan konstitusi kepada daerah dalam mengatur dan mengurus sendiri urusan pemerintahan. Dalam Pasal 1 angka 2, Undang-Undang Nomor 23 Tahun 2014 (Lemabaran Negara Republik Indonesia Tahun 2014 Nomor 244, Tambahan Lembaran Negara Republik Indonesia Nomor 5587), Pemerintahan daerah, secara yuridis, didefinisikan sebagai penyelenggaraan urusan pemerintahan oleh pemerintah daerah dan Dewan Perwakilan Rakyat Daerah dengan menganut asas otonomi daerah dan tugas pembantuan serta menganut prinsip otonomi seluas-luasnya sebagaimana dimaksud dalam Undang-Undang Dasar Negara Republik Indonesia tahun 1945. Penyelenggaraan urusan pemerintahan yang dimaksud merupakan penyelenggaraan kekuasaan pemerintahan yang menjadi kewenangan presiden. Akan tetapi, pelaksanaan kekuasaan tersebut dilakukan oleh kementerian negara dan penyelenggara pemerintahan daerah.

Secara umum, urusan pemerintahan terbagi menjadi urusan pemerintahan absolut, konkuren, dan umum. Urusan pemerintahan absolut merupakan kewenangan pemerintah pusat. Kemudian, urusan pemerintahan umum merupakan kewenangan presiden sebagai kepala pemerintahan. Urusan pemerintahan konkuren merupakan kewenangan yang diserahkan kepada daerah berdasarkan asas desentralisasi (Pasal 9, UU 23/2014). 
Berkaitan dengan asas desentralisasi, John R. Nellis, Dennis A. Rondinelli, dan G. Shabbir Cheema (dalam Asshiddiqie, 2006:27) mengatakan bahwa:

"decentralization is the transfer of planning, decision making, or administrative authority from the central government to its filed organizations, local government, or non-governmental organiaztion"

Hal ini diperkuat dengan kondisi wilayah Indonesia yang memiliki beragam jenis suku, budaya, potensi kekayaan alam yang berbeda-beda tiap daerah. Urusan pemerintahan konkuren diserahkan seluas-luasnya oleh pemerintah pusat ke daerah, dengan catatan bahwa kewenangan daerah dalam mengatur otonomi daerahnya tidak boleh mengatur urusan politik luar negeri, pertahanan, keamanan, yustisi, moneter dan fiskal nasional, serta agama rakyat (Pasal 10 Ayat (1), UU 23/2014). Berdasarkan hal di atas dapat dipahami bahwa pembentukan otonomi daerah lahir dari desentralisasi yang mengatur secara implisit tugas dan tanggung jawab utama pemerintah daerah dalam mensejahterakan (Saleh, 2008:3).

Pemerintahan daerah secara garis besar dibagi menjadi pemerintahan daerah provinsi dan pemerintahan daerah kabupaten/kota. Adapun Pemerintahan daerah Provinsi dipimpin oleh gubernur selaku wakil dari pemerintahan pusat di daerah yang memimpin pemerintahan daerah kabupaten/kota dalam wilayahnya. Pemerintahan daerah kabupaten/kota merupakan penyelenggaran pemerintahan daerah yang lebih kecil dari wilayah administrasi pemerintahan daerah provinsi. Pemerintahan daerah provinsi serta pemerintahan daerah kabupaten/kota memiliki tugas dan tanggung jawab yang sama, yaitu memastikan segala kebijakan dari pemerintah pusat dapat diberlakukan di daerah secara optimal serta memajukan masing-masing daerah. Upaya pemajuan daerah dilakukan melalui pembangunan daerah dengan tujuan meningkatkan dan melakukan pemerataan pendapatan masyarakat, kesempatan kerja, lapangan berusaha; meningkatkan akses dan kualitas pelayanan publik; serta daya saing daerah. Pembangunan daerah ini juga merupakan perwujudan dari pelaksanaan urusan pemerintahan yang telah diserahkan ke daerah sebagai bagian integral dari pembangunan nasional (Pasal 258 ayat (1), UU 23/2014). Sebagaimana yang disebutkan dalam UU 23/2014 pasal 258 ayat (1) dan (2):

\section{"Pasal 258}

(1)Daerah melaksanakan pembangunan untuk peningkatan dan pemerataan pendapatan masyarakat, kesempatan kerja, lapangan berusaha, meningkatkan akses dan kualitas pelayanan publik dan daya saing daerah.

(2) Pembangunan daerah sebagaimana dimaksud pada ayat (1) merupakan perwujudan dari pelaksanaan urusan pemerintahan yang telah diserahkan ke daerah sebagai bagian intergral dari pembangunan nasional."

Pemerintah daerah memiliki wewenang yang luas untuk melakukan pembangunan terhadap daerahnya. Menurut Soekartawi (dalam Setianingsih, dkk, Jurnal Administrasi Publik (JAP), Vol.3, Nomor 11), perencanaan pembangunan merupakan suatu proses yang berkesinambungan dari waktu ke waktu dengan melibatkan kebijakan pembuat keputusan berdasarkan sumber daya yang tersedia dan disusun secara sistematis.

Berdasarkan pasal 258 ayat (1) dan (2) di atas, secara sistematis Pembangunan Daerah merujuk pada ketentuan-ketentuan yang diatur dalam pembangunan nasional. Pembangunan nasional merupakan rangkaian upaya 
pembangunan yang berkesinambungan yang meliputi seluruh aspek kehidupan masyarakat, bangsa, dan negara (Lampiran Undang-Undang Republik Indonesia Nomor 17 Tahun 2007, hlm 8). Pembangunan nasional dituangkan dalam bentuk Rencana Pembangunan Jangka Panjang (RPJP) yang telah diberlakukan saat ini melalui Undang-Undang Nomor 17 tahun 2007 tentang Rencana Pembangunan Jangka Panjang 2005 2025. RPJP 2005 - 2025 menentukan bahwa arah pembangunan jangka panjang tahun 2005 - 2025 adalah mewujudkan bangsa yang berdaya saing melalui penguatan perekonomian domestik dengan orientasi dan berdaya saing global. Penguatan perekonomian domestik menjadi tugas penting bagi pemerintah daerah dengan memaksimalkan potensi masing-masing daerah berupa Sumber Daya Manusia, Sumber Daya Alam, dan lain-lain. Salah satu sektor yang dapat meramu potensi daerah serta melakukan pengembangan dalam RPJP 2005 - 2025 ini adalah sektor kepariwisataan yang berkaitan dengan pariwisata sebagai sarana untuk memenuhi kebutuhan wisatawan lokal maupun mancanegara untuk meningkatkan pemasukan daerah. Berdasarkan data statistik Badan Pusat Statistik (2018: 9) jumlah kunjungan wisatawan mancanegara mengalami peningkatan sejak lima tahun terakhir, sebagaimana ditunjukkan melalui gambar dibawah ini:

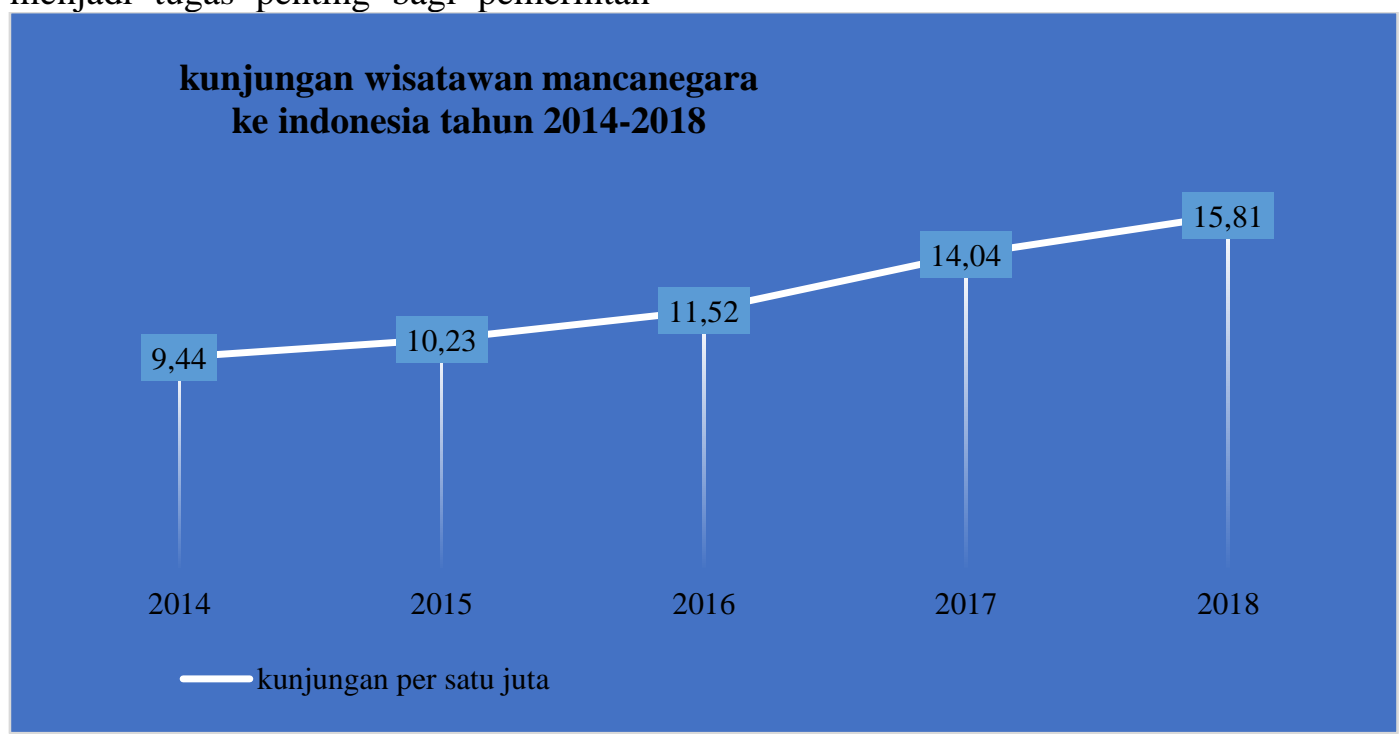

Gambar 1.1. Kedatangan Wisatawan Mancanegara 2014 - 2018

Sumber: katalog BPS: 8401011

Berdasarkan diagram tersebut, pada tahun 2018 sebanyak 15,81 juta wisatawan mancanegara melakukan kunjungan ke Indonesia. Dengan dukungan sebanyak 50 citra pariwisata nasional di Indonesia, jumlah wisatawan mancanegara akan bertambah. Apabila pariwisata di Indonesia semakin dikembangkan, akan berdampak pada meningkatnya jumlah wisatawan mancanegara. Selain itu, pariwisata juga memberi kontribusi terhadap Produk Domestik Bruto, sebagaimana dikutip dari Hasil Laporan Akhir Kementerian Pariwisata bekerjasama dengan Lembaga Penyelidikan Ekonomi dan Masyarakat Fakultas Ekonomi dan Bisnis Universitas Indonesia (2018), berikut ini:

"buku saku Kementerian Pariwisata tahun 2016 menyatakan bahwa kontribusi sektor pariwisata terhadap 
PDB adalah 9\%. Sementara BPS dalam kajiannya menunjukkan bahwa kontribusi pariwisata terhadap PDB hanya sebesar 4\%. Lebih lanjut World Travel and Tourism Council (WTTC) mengestimasi bahwa kontribusi sektor pariwisata Indonesia mencapai 5,8\% dari PDB."

Komposisi kepariwisataan di Indonesia terdiri atas tingkatan nasional sampai daerah yang terdiri dari keanekaragaman, keunikan, serta kekhasan budaya dan alam masingmasing daerah. Peranan daerah dalam membangun kepariwisataan daerah secara massive telah menjadi poin penting untuk membuka lapangan pekerjaan bagi masyarakat sekitar dengan memopulerkan daerah di tingkat nasional, sekaligus memberi kontribusi dalam peningkatan kepariwisataan nasional Indonesia (Oka, 2020:25). Sebagaimana disebutkan dalam Penjelasan Undang-Undang Nomor 10 Tahun 2009 tentang Kepariwisataan (Tambahan Lembaran Negara Republik Indonesia Nomor 4966, hlm. 2):

"Pembangunan kepariwisataan dikembangkan dengan pendekatan pertumbuhan dan pemerataan ekonomi untuk kesejahteraan rakyat dan pembangunan yang berorientasi pada pengembangan wilayah, bertumpu pada masyarakat yang mencakupi berbagai aspek."

Dalam Pasal 2-4, Peraturan Pemerintah Nomor 50 Tahun 2011 tentang Rencana Induk Pembangunan Kepariwisataan Nasional Tahun 2010-2025, Pembangunan kepariwisataan mencakup industri pariwisata, destinasi pariwisata, pemasaran, dan kelembagaan kepariwisataan yang diterapkan oleh masing-masing daerah berdasarkan Rencana Induk Pembangunan Kepariwisataan Nasional (RIPPARNAS). Pemerintah daerah wajib melakukan pembangunan kepariwisataan di masingmasing daerah dengan berpedoman pada RIPPARNAS, kemudian merumuskannya kedalam Rencana Induk Pembangunan
Kepariwisataan Daerah yang terdiri dari Rencana Induk Pembangunan Kepariwisataan Provinsi (RIPPARPROV) dan Rencana Induk Pembangunan Kepariwisataan Kabupaten/Kota (RIPPAR-KAB/KOTA). Hal demikian telah diamanatkan pada Pasal 8 UndangUndang Nomor 10 Tahun 2009 tentang Kepariwisataan yang menyebutkan bahwa pembangunan kepariwisataan yang dilakukan berdasarkan Rencana Induk Pembangunan Kepariwisataan merupakan bagian integral dari Rencana Pembangunan Jangka Panjang Nasional. Oleh karena itu, jangka waktu perencanaan RIPPARPROV dan RIPPARKAB/KOTA juga menyesuaikan dengan periode waktu Rencana Pembangunan Jangka Panjang Daerah Kabupaten/Kota yang tentu saja sama dengan periode waktu Rencana Pembangunan Jangka Panjang Nasional (Lampiran I huruf B Peraturan Menteri Pariwisata Republik Indonesia Nomor 10 Tahun 2016 tentang Pedoman Penyusunan Rencana Induk Pembangunan Kepariwisataan Provinsi Dan Kabupaten/Kota).

Lebih lanjut, dalam rangka menyinergikan penyusunan RIPPARPROV dan RIPPAR-KAB/KOTA, sebagaimana ketentuan dalam Pasal 5 Peraturan Pemerintah Nomor 50 Tahun 2011 tentang Rencana Induk Pembangunan Kepariwisataan Nasional Tahun 2010 - 2025, "untuk menyinergikan penyusunan Rencana Induk Pembangunan Kepariwisataan Provinsi dan Rencana Induk Pembangunan Kepariwisataan Kabupaten/Kota, sebagaimana dimaksud pasal 4, Pemerintah Daerah dapat melakukan konsultasi dan koordinasi dengan menteri,"

Menteri Pariwisata membentuk Peraturan Menteri Pariwisata Nomor 10 Tahun 2016 tentang Pedoman Penyusunan Rencana Induk Pembangunan Kepariwisataan Provinsi dan Kabupaten/Kota. Penyusunan Rencana Induk 
Pembangunan Pariwisata Daerah harus mencakup: landasan pembangunan kepariwisataan Indonesia, muatan materi, dan proses penyusunan (Pasal 1 ayat (1)).

Secara umum, penyusunan RIPPARPROV maupun RIPPAR-KAB/KOTA diberlakukan untuk periode 15 - 25 tahun yang disesuaikan dengan masa berlaku RIPPARNAS. Apabila RIPPARNAS yang berlaku saat ini adalah 2010 - 2025, seharusnya RIPPAR-PROV dan RIPPAR-KAB/KOTA yang diterbitkan oleh masing-masing daerah diberlakukan paling lama hingga tahun 2025 (Lampiran Peraturan Menteri Pariwisata Republik Indonesia Nomor 10 Tahun 2016 tentang Pedoman Penyusunan Rencana Induk Pembangunan Kepariwisataan Provinsi dan Kabupaten/Kota, hlm. 47). Akan tetapi, dalam prakteknya tidak berlaku demikian, di beberapa daerah, pemberlakuan RIPPAR-PROV maupun RIPPAR-KAB/KOTA tidak sesuai bahkan melampaui periode berlakunya RIPPARNAS. Hal ini disebut dengan disharmonisasi pemberlakuan Rencana Induk Pembangunan Kepariwisataan, seperti contoh pada tabel berikut.

Tabel 1.1 Komparasi Peraturan Daerah Terkait Periode Pemberlakuan RIPPAR-PROV dan RIPPAR-KAB/KOTA

\begin{tabular}{|c|l|l|c|}
\hline No. & Pemerintahan Daerah & Nomor Peraturan Daerah & Periode \\
\hline 1 & Provinsi Jawa Timur & 6 Tahun 2017 & $2017-2032$ \\
\hline 2 & Provinsi Jawa Tengah & 10 Tahun 2012 & $2012-2027$ \\
\hline 3 & Provinsi Sulawesi Selatan & 2 Tahun 2015 & $2015-2030$ \\
\hline 4 & Provinsi Sulawesi Tenggara & 5 Tahun 2016 & $2016-2031$ \\
\hline 5 & Provinsi Bali & 3 Tahun 2019 & $2018-2029$ \\
\hline 6 & Kota Balik Papan & 7 Tahun 2016 & $2016-2026$ \\
\hline 7 & Kota Surakarta & 13 Tahun 2016 & $2016-2026$ \\
\hline 8 & Kabupaten ciamis & 16 tahun 2016 & $2017-2027$ \\
\hline
\end{tabular}

*Hasil olahan data peraturan daerah Provinsi dan kabupaten/kota

Berdasarkan tabel di atas, terdapat lima provinsi dan tiga kabupaten/kota yang memberlakukan RIPPAR-PROV dan RIPPAR-KAB/KOTA melebihi periode pemberlakuan RIPPARNAS, yaitu di atas tahun 2025. Data di atas belum termasuk beberapa pemerintah daerah yang tidak mencantumkan periode pemberlakuan RIPPARPROV dan RIPPAR-KAB/KOTA dalam peraturan daerah, contohnya adalah Provinsi Kalimantan Timur dan Kota Malang, bahkan terdapat pemerintah daerah yang masih menggunakan RIPPAR-PROV yang terbit sebelum pemberlakuan RIPPARNAS, yaitu provinsi Banten (Berdasarkan hasil pencarian cepat terhadap beberapa daerah secara acak, dengan berfokus pada periode pemberlakuan Rencana Induk
Pembangunan Pariwisata Daerah yang melebihi tahun 2025). Kondisi ini memberikan pemahaman bahwa terjadi disharmonisasi periode pemberlakuan RIPPARNAS dengan RIPPAR-PROV dan RIPPAR-KAB/KOTA sehingga memunculkan pertanyaan mendasar di kalangan akademisi, bagaimana konsekuensi disharmonisasi periode pemberlakuan Rencana Induk Pembangunan Kepariwisataan (RIPPARNAS dengan RIPPARPROV dan RIPPAR-KAB/KOTA). Berdasarkan pemaparan di atas, penulis mengangkat 2 (dua) poin rumusan masalah, yaitu

1. Apa rasio legis Lingkup Kepariwisataan yang diatur melalui Rencana Induk Pembangunan Pariwisata oleh Daerah? 
2. Bagaimana konsekuensi dari disharmonisasi periode pemberlakuan Rencana Induk Pembangunan Kepariwisataan?

\section{METODE PENELITIAN}

Jenis penelitian ini adalah Yuridis Normatif, yaitu penelitian yang dilakukan dengan melihat asas-asas, baik tertulis maupun tidak tertulis, maupun konsep-konsep dalam peraturan perundang-undangan yang terkait dengan Rencana Induk Pembangunan Pariwisata dalam peraturan perundang-undangan di Indonesia. Metode pendekatan yang digunakan dalam penelitian ini adalah:

a. Pendekatan perundangundangan (statute-approach), yaitu menelaah peraturan Perundang-Undangan (Marzuki, 2011:96) yang terkait dengan pembangunan kepariwisataan di Indonesia yaitu Peraturan Pemerintah Nomor 50 Tahun 2011 tentang Rencana Induk Pembangunan Kepariwisataan.

b. Pendekatan kasus (case approach) pendekatan ini digunakan untuk menelaah beberapa kasus yang menjadi fokus dalam penelitian penulis. Kasus-kasus tersebut memiliki relevansi dengan isu yang diangkat, yaitu terkait dengan dishamonisasi periode RIPPAR yang terjadi di beberapa daerah.

c. Pendekatan konseptual (conceptual approach), yaitu menelaah dan memahami unsur atau konsep-konsep yang diperlukan terkait dengan kepariwisataan di Indonesia (Ibrahim, 2007:391).”

\section{HASIL DAN PEMBAHASAN}

1. Rasio Legis Lingkup

Kepariwisataan Untuk Diatur

Melalui Rencana Induk

Pembangunan Pariwisata oleh

Daerah

Otonomi Daerah merupakan amanat Pasal 1 UU Nomor 23 Tahun 2014 tentang Pemerintahan Daerah. Tujuan diselenggarakannya otonomi daerah adalah mengurangi beban pemerintah pusat, tercapainya efisiensi dan efektivitas layanan kepada masyarakat, memanfaatkan sumber daya dengan efektif, memantapkan perencanaan pembangunan daerah, meningkatkan persatuan dan kesatuan nasional, serta memberi kesempatan kepada masyarakat agar turut berpartisipasi dalam suatu kebijakan instansi pemerintahan (Hamid, 2011:537).

UU 23/2014 tentang Pemerintah Daerah juga mengenal Prinsip otonomi seluas-luasnya sebagaimana dijelaskan dalam Pasal 1:

"Pemerintahan Daerah adalah penyelenggaraan urusan pemerintahan oleh pemerintah daerah dan dewan perwakilan rakyat daerah menurut asas otonomi dan tugas pembantuan dengan prinsip otonomi seluasluasnya dalam sistem dan prinsip Negara Kesatuan Republik Indonesia sebagaimana dimaksud dalam UUD NRI 1945."

Otonomi Daerah yang seluasluasnya berarti daerah diberi kewenangan mengurus dan mengatur semua urusan pemerintahan di luar yang menjadi urusan pemerintah pusat yang ditetapkan dalam undang-undang 
pemerintahan daerah. Selain itu, pemerintah daerah diberi kewenangan membuat kebijakan daerah untuk memberi pelayanan, peningkatan peran, serta prakarsa dan pemberdayaan masyarakat yang bertujuan pada peningkatan kesejahteraan masyarakat (Jahidin, 2019:207). Sebagaimana diamanatkan UUD 1945, urusan pemerintahan menjadi kewenangan pemerintahan pusat yang disebut dengan urusan pemerintahan absolut dan konkuren.

Urusan pemerintahan absolut, sebagaimana dimaksud dalam Pasal 9 ayat (2) UU No. 23 Tahun 2014, ialah politik luar negeri, pertahanan, keamanan, yustisi, moneter dan fiskal nasional, dan agama. Urusan pemerintahan konkuren terdiri atas urusan pemerintahan wajib dan urusan pemerintahan pilihan yang dibagi antara pemerintah pusat, daerah provinsi, dan daerah kabupaten/kota. Urusan pemerintahan wajib dibagi menjadi urusan pemerintahan wajib yang terkait pelayanan dasar dan yang tidak terkait pelayanan dasar. Urusan pemerintahan wajib yang berkaitan dengan pelayanan dasar meliputi pendidikan; kesehatan; pekerjaan umum dan penataan ruang; perumahan rakyat dan kawasan permukiman; ketenteraman, ketertiban umum, dan pelindungan masyarakat; dan sosial. Urusan pemerintahan wajib yang tidak berkaitan dengan pelayanan dasar meliputi tenaga kerja; pemberdayaan perempuan dan pelindungan anak; pangan; pertanahan; lingkungan hidup; administrasi kependudukan dan pencatatan sipil; pemberdayaan masyarakat dan desa; pengendalian penduduk dan keluarga berencana; perhubungan; komunikasi dan informatika; koperasi, usaha kecil, dan menengah; penanaman modal; kepemudaan dan olah raga; statistik; persandian; kebudayaan; perpustakaan; dan kearsipan.

Selanjutnya, yang termasuk dalam urusan pemerintahan pilihan meliputi:

kelautan dan perikanan; pariwisata; pertanian; kehutanan; energi dan sumber daya mineral; perdagangan; perindustrian; dan transmigrasi. Kemudian, penyelenggaraan urusan pemerintahan bidang kehutanan, kelautan, serta energi dan sumber daya mineral dibagi antara pemerintah pusat dan daerah provinsi. Urusan pemerintahan bidang kehutanan yang berkaitan dengan pengelolaan taman hutan raya kabupaten/kota menjadi kewenangan daerah kabupaten/kota. Urusan pemerintahan bidang energi dan sumber daya mineral yang berkaitan dengan pengelolaan minyak dan gas bumi menjadi kewenangan pemerintah pusat. Urusan pemerintahan bidang energi dan sumber daya mineral yang berkaitan dengan pemanfaatan langsung panas bumi dalam daerah kabupaten/kota menjadi kewenangan daerah kabupaten/kota.

Berdasarkan paparan di atas, sektor pariwisata merupakan salah satu sektor yang dikelola oleh daerah berdasarkan urusan pemerintahan pilihan. Sektor pariwisata juga merupakan salah satu agenda pembangunan nasional melalui pembangunan daerah. Pasal 258 ayat (1) UU 23/2014 mengamanatkan kepada daerah agar melaksanakan pembangunan dalam rangka peningkatan dan pemerataan 
pendapatan masyarakat, kesempatan kerja, lapangan berusaha, meningkatkan akses dan kualitas pelayanan publik dan daya saing daerah (UU 10/2009). Berikut tabel pembagian urusan pemerintahan bidang pariwisata:

Tabel 1.2 Pembagian Urusan Pemerintahan Bidang Pariwisata

\begin{tabular}{|c|c|c|c|}
\hline Sub Urusan & Pemerintah Pusat & Daerah Provinsi & Daerah Kab/Kota \\
\hline $\begin{array}{l}\text { Destinasi } \\
\text { Pariwisata }\end{array}$ & $\begin{array}{l}\text { a. Penetapan daya tarik wisata, } \\
\text { kawasan strategis pariwisata, } \\
\text { dan destinasi pariwisata. } \\
\text { b. Pengelolaan daya tarik wisata } \\
\text { nasional. } \\
\text { c. Pengelolaan kawasan } \\
\text { strategis pariwisata nasional. } \\
\text { d. Pengelolaan destinasi } \\
\text { pariwisata nasional. } \\
\text { e. Penetapan tanda daftar usaha } \\
\text { pariwisata lintas Daerah } \\
\text { provinsi. }\end{array}$ & $\begin{array}{ll}\text { a. } & \begin{array}{l}\text { Pengelolaan daya tarik } \\
\text { wisata provinsi. }\end{array} \\
\text { b. } & \begin{array}{l}\text { Pengelolaan kawasan } \\
\text { strategis pariwisata } \\
\text { provinsi. }\end{array} \\
\text { c. Pengelolaan destinasi } & \begin{array}{l}\text { Pean } \\
\text { pariwisata provinsi. }\end{array} \\
\text { d. Penetapan tanda daftar } \\
\text { usaha pariwisata lintas } \\
\text { Daerah kabupaten/kota } \\
\text { dalam 1 (satu) Daerah } \\
\text { provinsi. }\end{array}$ & $\begin{array}{l}\text { a. Pengelolaan daya tarik } \\
\text { wisata kabupaten/kota. } \\
\text { b. Pengelolaan kawasan } \\
\text { strategis pariwisata } \\
\text { kabupaten/kota. } \\
\text { c. Pengelolaan destinasi } \\
\text { pariwisata } \\
\text { kabupaten/kota. } \\
\text { d. Penetapan tanda daftar } \\
\text { usaha pariwisata } \\
\text { kabupaten/kota. }\end{array}$ \\
\hline $\begin{array}{l}\text { Pemasaran } \\
\text { Pariwisata }\end{array}$ & $\begin{array}{l}\text { Pemasaran pariwisata dalam } \\
\text { dan luar negeri daya tarik, } \\
\text { destinasi dan kawasan } \\
\text { strategis pariwisata nasional. }\end{array}$ & $\begin{array}{l}\text { Pemasaran pariwisata dalam } \\
\text { dan luar negeri daya tarik, } \\
\text { destinasi dan kawasan } \\
\text { strategis pariwisata provinsi. }\end{array}$ & $\begin{array}{l}\text { Pemasaran pariwisata } \\
\text { dalam dan luar negeri daya } \\
\text { tarik, destinasi dan } \\
\text { kawasan strategis } \\
\text { pariwisata kab/kota. }\end{array}$ \\
\hline $\begin{array}{l}\text { Pengembanga } \\
\text { n Sumber } \\
\text { Daya } \\
\text { Pariwisata } \\
\text { dan Ekraf }\end{array}$ & $\begin{array}{l}\text { Pengembangan,penyelenggaraa } \\
\mathrm{n} \text { dan peningkatan kapasitas } \\
\text { sumber daya manusia pariwisata } \\
\text { dan ekonomi kreatif tingkat ahli }\end{array}$ & $\begin{array}{l}\text { Pelaksanaan peningkatan } \\
\text { kapasitas sumber daya } \\
\text { manusia pariwisata dan } \\
\text { ekonomi kreatif tingkat } \\
\text { lanjutan. }\end{array}$ & $\begin{array}{l}\text { Pelaksanaan peningkatan } \\
\text { kapasitas sumber daya } \\
\text { manusia pariwisata dan } \\
\text { ekonomi kreatif tingkat } \\
\text { dasar. }\end{array}$ \\
\hline
\end{tabular}

Dapat disimpulkan dari tabel di atas bahwa daerah diberi kewenangan untuk melakukan pengelolaan terhadap pariwisata yang terdapat di daerah masing-masing. Hal ini meliputi urusan destinasi wisata, pemasaran wisata, pengembangan sumber daya pariwisata, dan ekonomi kreatif. Istilah pariwisata berbeda dengan kepariwisataan. Merujuk pada UU Kepariwisataan, pariwisata adalah berbagai macam kegiatan wisata dan didukung berbagai fasilitas serta layanan yang disediakan oleh masyarakat, pengusaha, pemerintah, dan pemerintah daerah. Kepariwisataan adalah keseluruhan kegiatan yang terkait dengan pariwisata dan bersifat multidimensi serta multidisiplin yang muncul sebagai wujud kebutuhan setiap orang dan negara serta interaksi antara wisatawan dan masyarakat setempat, sesama wisatawan, pemerintah, pemerintah daerah, dan pengusaha (Pasal 1, UU 10/2009).

Berdasarkan pemaparan tersebut, jika merujuk pada strategi RIPPARNAS 2010 - 2025, daerah yang memiliki potensi kepariwisataan berhak dan berwenang melakukan pengembangan atas sektor tersebut. Selain senalar dengan prinsip pembangunan daerah berdasarkan pada asas otonomi, kondisi tersebut juga berpengaruh terhadap kesehatan perekonomian daerah untuk mensejahterakan masyarakat. Pada lain sisi, daerah juga perlu memperhatikan komponen pariwisata. Setidaknya terdapat beberapa komponen pariwisata yang digunakan untuk mengembangkan 
sektor pariwisata, yakni pembangunan destinasi pariwisata nasional, seperti pembangunan daya tarik pariwisata, pembangunan aksesbilitas pariwisata, pembangunan prasarana umum; peningkatan struktur industri pariwisata, seperti peningkatan daya saing produk pariwisata; dan pemasaran pariwisata nasional, seperti pengembangan pasar wisatawan, dan promosi pariwisata.

\section{Konsekuensi dari Disharmonisasi Periode Pemberlakuan Rencana Induk Pembangunan Kepariwisataan}

Pembangunan kepariwisataan merupakan bagian integral dari pembangunan nasional. Oleh karena itu, RIPPAR tersebut harus merujuk kepada Rencana Pembangunan Jangka Panjang Nasional (RPJPN) yang tertuang dalam UU Nomor 17 Tahun 2007 untuk menciptakan sinkronisasi dan harmonisasi agar tercipta integrasi, sinkronisasi, dan sinergi antardaerah, antarruang, antarwaktu, dan antarfungsi pemerintah. Jangka waktu target pembangunan nasional dalam RPJP Nasional untuk periode 20 (dua puluh) tahun terhitung sejak tahun 2005 sampai dengan tahun 2025. Hal ini juga berlaku pada RPJP Daerah yang terhitung sejak tahun 2005 2025. Kurun waktu RPJP Daerah sesuai dengan kurun waktu RPJP Nasional (Pasal 1 UU Nomor 17 Tahun 2007 tentang Rencana Pembangunan Jangka Panjang Nasional Tahun 2005 - 2025). Pasal 6 UU Nomor 17 Tahun 2007 menyebutkan,
"RPJP Nasional menjadi acuan dalam penyusunan RPJP Daerah yang memuat visi, misi, dan arah RPJP Daerah." RPJP Daerah dalam sektor kepariwisataan diimplementasikan melalui Peraturan Daerah tentang RIPP Daerah Provinsi dan Kabupaten/Kota. RPJP Nasional menjadi acuan RPJP daerah bukan bermaksud untuk membatasi wewenang daerah dalam otonomi daerah, melainkan agar terdapat acuan peraturan yang jelas, sinergi, dan keterkaitan setiap pembangunan daerah yang didasarkan atas kewenangan otonomi yang dimiliki. Akan tetapi, ada RIPP Daerah Provinsi yang tidak menyesuaikan jangka waktu pembangunan nasional yang tercantum dalam RPJP Nasional yakni 2005 - 2025.

Pasal 1 Angka 3 PP Nomor 50 Tahun 2011 Tentang RIPPARNAS menyebutkan bahwa Rencana Induk Pembangunan Kepariwisataan Nasional yang selanjutnya disebut dengan RIPPARNAS adalah dokumen perencanaan pembangunan kepariwisataan nasional untuk periode 15 tahun terhitung sejak tahun 2010 sampai dengan tahun 2025. Seharusnya, penyusunan RIPP Daerah Provinsi maupun RIPP Daerah Kabupaten/Kota menyesuaikan RPJP Nasional dan PP 50/2011 yang berlaku paling lama pada tahun 2025, seperti contoh pada tabel berikut:

Tabel 1.4 Relasi Disharmonisasi Periode

\begin{tabular}{|c|c|c|}
\hline RIPNAS & Perda Provinsi/ Kabupaten/Kota & $\begin{array}{c}\text { Jangka Waktu } \\
\text { RIPPARDA }\end{array}$ \\
\hline $2010-2025$ & Perda Prov Jawa Timur Nomor 6 Tahun 2017 & $2017-2032$ \\
\cline { 2 - 3 } & Perda Prov Bali Nomor 10 Tahun 2015 & $2015-2029$ \\
\hline
\end{tabular}




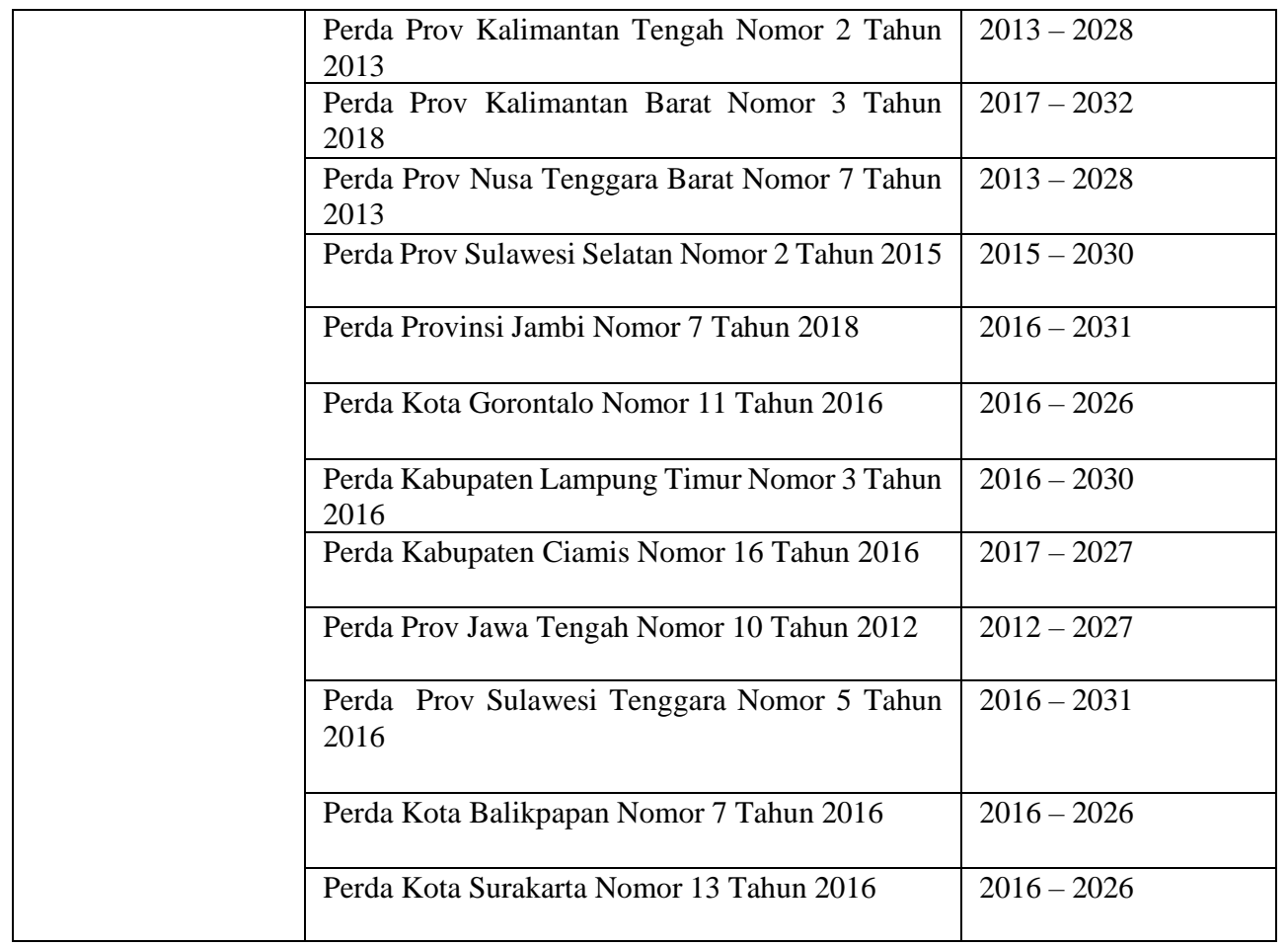

Sumber: diolah dari berbagai sumber, 2020

Tabel di atas menunjukkan ketidaksinkronan jangka waktu pembangunan pariwisata yang terdapat di daerah-daerah provinsi maupun kabupaten/kota terhadap RIPPARNAS. Pasal 3 PP 50/2011 menjelaskan bahwa pelaksanaan RIPPARNAS sebagaimana dimaksud diselenggarakan secara terpadu oleh pemerintah dan pemerintah daerah sesuai kewenangannya, dunia usaha, dan masyarakat. Hal tersebut berarti bahwa penyelenggaraan jangka waktu RIPPARDA oleh pemerintah daerah harus selaras dengan RIPPARNAS dan PP 50/2011 dan dilaksanakan sesuai dengan kewenangan pemerintah daerah yang telah diatur dalam Pasal 2 PP 50/2011, seperti kewenangan pembangunan kepariwisataan nasional yang meliputi destinasi pariwisata, pemasaran pariwisata, industri pariwisata, dan kelembagaan kepariwisataan.

Dalam UU Nomor 12 Tahun 2011 tentang peraturan perundangundangan terdapat jenis dan hierarki peraturan perundang-undangan yang terdiri atas Undang-Undang Dasar Negara Republik Indonesia Tahun 1945, Ketetapan Majelis Permusyawaratan Rakyat, UndangUndang/Peraturan Pemerintah Pengganti Undang-Undang, Peraturan Presiden, Peraturan Daerah Provinsi, dan Peraturan Daerah Kabupaten/Kota. Sesuai hierarki tersebut, Perda Provinsi dan Perda Kabupaten/Kota harus menyesuikan tingkat perundang-undangan di atasnya berdasarkan asas lex superior derogat legi inferiori. Lebih lanjut, untuk melihat konsekuensi dari tidak sinkronnya periode pemberlakuan Rencana Induk Pariwisata, dapat 


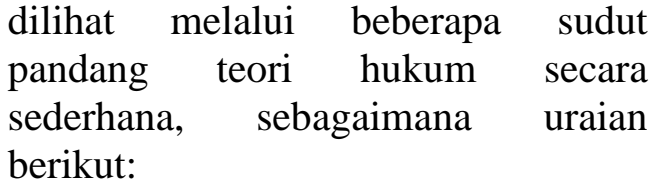

\section{a. Sudut Pandang Teori Sinkronisasi dan Harmonisasi Hukum}

Isu disharmonisasi tidak akan terlepas dari teori sinkronisasi. Hal demikian dikarenakan teori sinkronisasi merupakan sudut pandang yang digunakan untuk melihat keselarasan atau kesesuaian perundang-undangan secara vertikal dengan cara sistematisasi hukum positif, yaitu antara peraturan perundangundangan yang lebih tinggi dengan peraturan perundang-undangan yang lebih rendah (Sumiarni, 2013:5). Sinkronisasi menjadi elemen yang berperan untuk melihat keselarasan suatu Perda agar memperhatikan asas-asas yang berlaku bagi ketentuan peraturan perundangundangan. Peter Mahmud Marzuki berpendapat bahwa terdapat asas lex superiori derogat legi inferiori dalam sinkronisasi peraturan perundangundangan. Hal tersebut berkaitan dengan pertentangan yang terjadi antara peraturan perundang-undangan yang secara hierarkis lebih rendah dengan yang secara hierarkis lebih tinggi. Dengan demikian, peraturan perundang-undangan yang hierarkinya lebih rendah harus dikesampingkan (Marzuki, 2011:99).

Sinkronisasi hukum merupakan penyelarasan dan penyerasian berbagai peraturan perundang-undangan yang terkait dengan peraturan perundangundangan yang telah ada dan sedang disusun yang mengatur suatu bidang tertentu. Sinkronisasi peraturan perundang-undangan ini juga bertujuan untuk mewujudkan landasan pengaturan suatu bidang tertentu yang dapat memberikan kepastian hukum yang memadai bagi penyelenggaraan bidang tertentu secara efisien dan efektif (Sayuna, 2016; Hantoro, 2012). Sinkronisasi diharapkan menjadi analisis komplementer terhadap kepastian hukum yang dipaparkan sebelumnya.

Harmonisasi peraturan perundangundangan dapat diartikan sebagai suatu proses penyelarasan atau penyerasian peraturan perundang-undangan yang hendak atau sedang disusun agar peraturan perundang-undangan yang dihasilkan sesuai prinsip-prinsip hukum dan peraturan perundang-undangan yang baik (Rochim, 2014). Hal demikian berkonsekuensi bahwa teori harmonisasi terlebih dahulu digunakan dalam pemilihan materi muatan maupun prinsip/asas pada proses pembentukan perundang-undangan, dan teori sinkronisasi merupakan alat dalam melihat keselarasan secara hirarki dan subtansi pada peraturan perundangundangan tersebut.

Dalam Penyusunan Rencana Induk Pariwisata, pemerintah pusat merujuk pada jangka/periode pemberlakuan pada Undang-Undang Nomor 25 Tahun 2000 tentang Program Pembangunan Nasional yang berlaku hingga tahun 2025 dan PP Nomor 50 Tahun 2011 tentang RIPPARNAS dokumen perencanaan pembangunan kepariwisataan nasional untuk periode 15 tahun terhitung sejak tahun 2010 sampai dengan tahun 2025

Konstruksi ini menjelaskan bahwa salah satu program pembangunan adalah program pembentukan peraturan perundang-undangan yang sasarannya adalah menciptakan harmonisasi peraturan perundang-undangan yang sesuai dengan aspirasi masyarakat dan kebutuhan pembangunan. Pasal 46 ayat (2) Undang-Undang Nomor 12 Tahun 2011 tentang Pembentukan Peraturan Perundang-Undangan menentukan bahwa pengharmonisasian, pembulatan, dan pemantapan konsepsi Rancangan Undang-Undang yang berasal dari DPR dikoordinasikan oleh alat kelengkapan DPR yang khusus menangani bidang legislasi begitu pula yang terjadi di daerah. 
Berdasarkan pendapat Moh. Hasan Wargakusumah dalam Suhartono, harmonisasi hukum adalah kegiatan ilmiah menuju proses pengharmonisasian tertulis yang mengacu pada nilai-nilai filosofis, sosiologis, ekonomis maupun yuridis (Suhartono, 2011:94). Berkaitan dengan pandangan teori ini, sektor pembangunan daerah telah dibatasi legitimasinya melalui Peraturan Daerah sebagaimana diamanatkan pada Pasal 236 ayat (1) bahwa "Untuk menyelenggarakan Otonomi Daerah dan Tugas Pembantuan, Daerah membentuk Perda."

Pembatasan Perda ini juga dijelaskan melalui penjelasan Undang-Undang Nomor 23 tahun 2014 tentang Pemerintah Daerah bahwa dalam pelaksanaan urusan pemerintahan yang menjadi kewenangan daerah, kepala daerah dan DPRD selaku penyelenggara pemerintahan daerah membuat Perda sebagai dasar hukum bagi daerah dalam menyelenggarakan otonomi daerah sesuai dengan kondisi dan aspirasi masyarakat serta kekhasan dari daerah tersebut. Perda yang dibuat oleh daerah hanya berlaku dalam batas-batas yuridiksi daerah yang bersangkutan. Walaupun demikian Perda yang ditetapkan oleh daerah tidak boleh bertentangan dengan ketentuan peraturan perundang-undangan yang lebih tinggi tingkatannya sesuai dengan hierarki peraturan perundangundangan. Di samping itu, Perda sebagai bagian dari sistem peraturan perundangundangan tidak boleh bertentangan dengan kepentingan umum sebagaimana diatur dalam kaidah penyusunan Perda.

Kondisi demikian mensyaratkan bahwa UU 23/2014 tentang Pemerintah Daerah tidak membenarkan suatu peraturan daerah bertentangan dengan peraturan lainnya yang lebih tinggi sehingga jelas implementasi teori sinkronisasi-harmonisasi tertuang dalam UU 23/2014. Hal ini sama dengan UU 10/2009 tentang Kepariwisataan Pasal 8 bahwa
(1) Pembangunan kepariwisataan dilakukan berdasarkan rencana induk pembangunan kepariwisataan yang terdiri atas rencana induk pembangunan kepariwisataan nasional, rencana induk pembangunan kepariwisataan provinsi, dan rencana induk pembangunan kepariwisataan kabupaten/kota.

(2) Pembangunan kepariwisataan sebagaimana dimaksud pada ayat (1) merupakan bagian integral dari rencana pembangunan jangka panjang nasional.

Konstruksi Pasal 8 ayat (1) berkonsekuensi terhadap dibentuknya Rencana Induk Pembangunan Kepariwisataan wajib menjadi bagian integral terhadap Rencana Pembangunan Jangka Panjang Nasional. Meskipun tidak ada penegasan bahwa rencana induk pembangunan kepariwisataan provinsi dan rencana induk pembangunan kepariwisataan kabupaten/kota wajib integral dan sinkron dengan rencana induk pembangunan kepariwisataan nasional, tetapi kerangka penyusunan rencana induk pembangunan kepariwisataan nasional sebagaimana diatur dalam Peraturan Pemerintah No. 50 Tahun 2011 tentang Rencana Induk Pembangunan Kepariwisataan Nasional Tahun 2010 2025, senalar dan selaras dengan Rencana Pembangunan Jangka Panjang Nasional yang berakhir pada Periode 2025 .

Kondisi demikian berkonsekuensi bahwa ketentuan integral dan harmonisnya Rencana Induk Pariwisata melalui Peraturan Daerah memiliki jangka waktu tertentu. Hasilnya, sebagaimana disebutkan sebelumnya, beberapa Rencana Induk Pariwisata, seperti Perda Prov Jawa Timur Nomor 6 Tahun 2017, Perda Prov Bali Nomor 10 Tahun 2015, dan Perda Prov Kalimantan Tengah Nomor 2 Tahun 2013 merupakan bagian integral dan selaras namun hanya sampai pada masa RPJPN dan RIPPARNAS di 
tahun 2025. Hal ini berbanding terbalik dengan beberapa produk hukum lainnya yang secara hierarkis mengalami konflik/kecacatan material karena tidak bersifat integral atau selaras dengan Rencana Induk Pembangunan Kepariwisataan Nasional Tahun 2010 2025 sebagaimana disebutkan dalam Tabel. 1.4. Berkaca dari teori ini, peraturan daerah yang disebutkan di atas dapat dilakukan pembatalan dikarenakan tidak terpenuhinya asas "kesesuaian antara jenis, hierarki, dan materi muatan" sebagaimana dicantumkan dalam Pasal 5 Undang-Undang 12/2011 tentang Pembentukan Peraturan PerundangUndangan.

\section{b. Sudut Pandang Teori \\ Pembangunan Hukum}

Apabila melihat teori pembangunan hukum yang dicetuskan oleh Mochtar Kusumaatmadja (2002:14) dalam Mulyadi (2020), pembangunan hukum terdapat pola kerja sama dengan melibatkan keseluruhan pemangku kepentingan yang ada dalam komunitas sosial dalam sebuah tujuan dari hukum. Secara sederhana, Kusumaatmadja menegaskan bahwa terdapat perubahan pengertian hukum sebagai alat menjadi hukum sebagai sarana untuk membangunan masyarakat. Hal ini lebih tegas dalam pengertian hukum sebagai sarana tidak menegaskan sifat legisme dalam hukum. Hal demikian dikarenakan:

a. Di Indonesia peran perundangundangan dalam proses pembaharuan hukum lebih menonjol, misalnya jika dibandingkan dengan Amerika Serikat yang menempatkan yurisprudensi (khususnya putusan the Supreme Court) pada tempat lebih penting.

b. Konsep hukum sebagai "alat" akan mengakibatkan hasil yang tidak jauh berbeda dengan penerapan "legisme" sebagaimana pernah diadakan pada zaman Hindia Belanda, dan di Indonesia ada sikap yang menunjukkan kepekaan masyarakat untuk menolak penerapan konsep seperti itu.

c. Apabila "hukum" termasuk juga hukum internasional, maka konsep hukum sebagai sarana pembaharuan masyarakat sudah diterapkan jauh sebelum konsep ini diterima secara resmi sebagai landasan kebijakan hukum nasional (Shidarta, 2016:415)

Lebih detil Mochtar Kusumaatmadja mengatakan, "Hukum merupakan suatu alat untuk memelihara ketertiban dalam masyarakat. Mengingat fungsinya sifat hukum, pada dasarnya adalah konservatif artinya, hukum bersifat memelihara dan mempertahankan yang telah tercapai. Fungsi demikian diperlukan dalam setiap masyarakat, termasuk masyarakat yang sedang membangun, karena di sini pun ada hasil-hasil yang harus dipelihara, dilindungi dan diamankan. Akan tetapi, masyarakat yang sedang membangun, yang dalam difinisi kita berarti masyarakat yang sedang berubah cepat, hukum tidak cukup memiliki memiliki fungsi demikian saja. Ia juga harus dapat membantu proses perubahan masyarakat itu. Pandangan yang kolot tentang hukum yang menitikberatkan fungsi pemeliharaan ketertiban dalam arti statis, dan menekankan sifat konservatif dari hukum, menganggap bahwa hukum tidak dapat memainkan suatu peranan yang berarti dalam proses pembaharuan."(Mulyadi, 2020)

Memasukkan teori pembangunan hukum dalam analisis kesenjangan Pembentukan Rencana Induk Pariwisata pada tingkat daerah menjadi hal yang menarik. Hal demikian dikarenakan terdapat potensi pembenar dalam teori pembangunan hukum bahwa daerah mengetahui kondisi wilayahnya secara demografi, ekologi, maupun ekonomi. 
Komponen pengetahuan tersebut juga mengarahkan daerah agar mampu mengidentifikasi potensi dalam pembangunan pariwisata serta jangka waktu realisasi sektor pariwisata.

Penyimpulan sederhana dari syaratsyarat tersebut tidak jauh bahwa dalam pembangunan hukum, visi-misi kepala daerah yang mampu menggerakkan perangkat daerah, badan usaha daerah, dan masyarakat sebagai syarat (keseluruhan stakeholders) merupakan syarat pertama yang harus dipenuhi. Syarat kedua yaitu komunitas sosial yang diinterpretasikan sebagai wilayah yang akan dipengaruhi oleh hukum, yaitu daerah tempat berlakunya Peraturan Daerah tentang Rencana Induk Pariwisata. Syarat terakhir adalah semuanya terangkum dalam tujuan hukum yaitu keadilan, kepastian, dan kebermanfaatan.

Konsekuensi dari syarat-syarat ini mengindikasikan bahwa penggalian potensi pariwisata baru dilakukan pasca kepala daerah memiliki visi-misi/program yang condong terhadap pembangunan pariwisata daerah, sehingga berpotensi terjadi keterlambatan penyusunan RIPPAR-DA dengan RIPPAR-NAS. Sebagaimana disebutkan di atas, terkait dengan disharmoninsasi RIPPAR-DA dengan RIPPARNAS, apabila didalami visi-misi dan pergantian Kepala Daerah akan ditemui data Tabel 1.5.

Akibatnya, melalui perhitungan yang logis terhadap rangkaian pembangunan pariwisata daerah baik pada sektor industri pariwisata, destinasi pariwisata, pemasaran, dan kelembagaan kepariwisataan memiliki perhitungan rencana waktu yang tidak cukup apabila mengharuskan sesuai dengan waktu pemberlakuan RIPPAR-NAS. Hasilnya, kajian penyusunan Rencana Induk Pembangunan Pariwisata Daerah cenderung memiliki Periode yang lebih lama dan melebihi periode berlakunya
RIPPARNAS.

Berdasarkan paparan di atas, konsekuensi dari perbedaan periode waktu berlakunya Rencana Induk pariwisata dapat dilihat melalui 2 (dua) sudut pandang. Secara teori sinkronisasi-harmonisasi hukum yang berdasarkan pada pemahaman Undang-Undang Pemerintah Daerah, Undang-Undang Kepariwisataan, dan Undang-Undang Pembentukan Peraturan Daerah, RIPPARDA yang memiliki periode waktu melebihi RIPPARNAS dapat dibatalkan melalui uji material karena bertentangan dengan peraturan di atasnya. Berdasarkan sudut pandang pembangunan hukum, hal tersebut dibenarkan dengan dalih efesiensi dan keselarasan antara berbagai pemangku kepentingan terkait, di lain sisi juga merupakan konsekuensi dari hasil kajian penyusunan rencana induk pembangunan pariwisata agar mampu dilaksanakan secara optimal pada sektor industri pariwisata, destinasi pariwisata, pemasaran, dan kelembagaan kepariwisataan. 
Tabel 1.5 Visi Misi Pergantian Kepala Daerah

\begin{tabular}{|c|c|c|c|c|c|}
\hline \multirow[t]{2}{*}{ No } & \multirow{2}{*}{$\begin{array}{l}\text { Perda Provinsi/Kab/ } \\
\text { Kota }\end{array}$} & \multirow{2}{*}{$\begin{array}{c}\text { Jangka } \\
\text { Waktu } \\
\text { RIPPARDA }\end{array}$} & \multirow{2}{*}{$\begin{array}{c}\text { Tahun Pergantian } \\
\text { Kepala Daerah } \\
\text { Sebelum } \\
\text { dibentuknya } \\
\text { RIPPAR } \\
\end{array}$} & \multicolumn{2}{|c|}{ Terdapat Visi/ Misi/ Program tentang Pariwisata } \\
\hline & & & & $\begin{array}{l}\text { Sebelum } \\
\text { Pergantian }\end{array}$ & Pasca Pergantian \\
\hline 1 & $\begin{array}{l}\text { Perda Prov Jawa } \\
\text { Timur Nomor } 6 \\
\text { Tahun } 2017\end{array}$ & $2017-2032$ & 2013 & $\begin{array}{c}2008 \\
\text { Tidak ada }\end{array}$ & $\begin{array}{l}2013 \\
\text { Ada, Misi keenam bidang } \\
\text { perdagangan, pariwisata dan } \\
\text { investasi }\end{array}$ \\
\hline 2 & $\begin{array}{l}\text { Perda Prov } \text { Bali } \\
\text { Nomor } 10 \text { Tahun } 2015\end{array}$ & $2015-2029$ & 2013 & $\begin{array}{l}2008 \\
\text { Ada, daerah tujuan } \\
\text { wisatarang } \\
\text { handal } \\
\end{array}$ & $\begin{array}{l}2013 \\
\text { Ada, pariwisata }\end{array}$ \\
\hline 3 & $\begin{array}{lr}\text { Perda } & \text { Prov } \\
\text { Kalimantan } & \text { Tengah } \\
\text { Nomor 2 Tahun 2013 }\end{array}$ & $2013-2028$ & 2010 & $\begin{array}{l}2005 \\
\text { Tidak ada }\end{array}$ & $\begin{array}{l}2010 \\
\text { Ada, Pertanian, industry, } \\
\text { pariwisata, pertambangan, } \\
\text { perdagangan dan jasa }\end{array}$ \\
\hline 4 & $\begin{array}{lr}\text { Perda } & \text { Prov } \\
\text { Kalimantan } & \text { Barat } \\
\text { Nomor 3 Tahun } & 2018\end{array}$ & $2017-2032$ & 2018 & $\begin{array}{l}2013 \\
\text { Tidak ada }\end{array}$ & $\begin{array}{l}\text { Ada, Infrastuktur, pariwisata, } \\
\text { kesehatan, pertanian }\end{array}$ \\
\hline 5 & $\begin{array}{ll}\text { Perda Prov } & \text { Nusa } \\
\text { Tenggara } & \text { Barat } \\
\text { Nomor } 7 \text { Tahun } & 2013\end{array}$ & $2013-2028$ & 2013 & $\begin{array}{l}2008 \\
\text { Ada, pariwisata, } \\
\text { kesehatan }\end{array}$ & $\begin{array}{l}2013 \\
\text { Ada, Infrastuktur, pariwisata, }\end{array}$ \\
\hline 6 & $\begin{array}{l}\text { Perda Prov Sulawesi } \\
\text { Selatan Nomor } 2 \\
\text { Tahun } 2015\end{array}$ & $2015-2030$ & 2013 & $\begin{array}{l}2008 \\
\text { Tidak ada }\end{array}$ & $\begin{array}{l}2013 \\
\text { Ada, Ketertiban, infrastuktur, } \\
\text { pariwisata }\end{array}$ \\
\hline 7 & $\begin{array}{l}\text { Perda Provinsi Jambi } \\
\text { Nomor } 7 \text { Tahun } 2018\end{array}$ & $2016-2031$ & 2018 & $\begin{array}{l}2016 \\
\text { Tidak ada }\end{array}$ & $\begin{array}{l}2018 \\
\text { Ada, Pariwisata, infrastuktur, } \\
\text { pertanian }\end{array}$ \\
\hline 8 & $\begin{array}{l}\text { Perda Kota Gorontalo } \\
\text { Nomor } 11 \text { Tahun } 2016\end{array}$ & $2016-2026$ & 2014 & - & $\begin{array}{l}2014 \\
\text { Ada, Pariwisata, infrastuktur, } \\
\text { UMKM, reformasi birokrasi }\end{array}$ \\
\hline 9 & $\begin{array}{lr}\text { Perda } & \text { Kabupaten } \\
\text { Lampung } & \text { Timur } \\
\text { Nomor } 3 & \text { Tahun } 2016\end{array}$ & $2016-2030$ & 2015 & $\begin{array}{l}2012 \\
\text { Tidak ada }\end{array}$ & $\begin{array}{l}2015 \\
\text { Ada, pariwista }\end{array}$ \\
\hline 10 & \begin{tabular}{lr} 
Perda & \multicolumn{2}{r}{ Kabupaten } \\
Ciamis Nomor 16 \\
Tahun 2016
\end{tabular} & $2017-2027$ & 2014 & $\begin{array}{l}2009 \\
-\end{array}$ & $\begin{array}{l}2014 \\
\text { Ada, pariwisata }\end{array}$ \\
\hline 11 & $\begin{array}{l}\text { Perda Prov Jawa } \\
\text { Tengah Nomor } 10 \\
\text { Tahun } 2012 \\
\end{array}$ & $2012-2027$ & 2008 & $\begin{array}{l}2007 \\
-\end{array}$ & $\begin{array}{l}2008 \\
\text { Ada, Pariwisata, Reformasi } \\
\text { birokrasi, pendidikan }\end{array}$ \\
\hline 12 & $\begin{array}{l}\text { Perda Prov Sulawesi } \\
\text { Tenggara 5 Tahun } \\
2016\end{array}$ & $2016-2031$ & 2013 & $\begin{array}{l}2008 \\
\text { Tidak ada }\end{array}$ & $\begin{array}{l}2013 \\
\text { Ada, Pariwisata, infrastuktur }\end{array}$ \\
\hline 13 & $\begin{array}{l}\text { Perda } \quad \text { Kota } \\
\text { Balikpapan Nomor } 7 \\
\text { Tahun 2016 }\end{array}$ & $2016-2026$ & 2016 & $\begin{array}{l}2011 \\
-\end{array}$ & $\begin{array}{l}2016 \\
\text { Ada, Pariwisata, pendidikan, } \\
\text { budaya }\end{array}$ \\
\hline 14 & $\begin{array}{l}\text { Perda Kota Surakarta } \\
\text { Nomor } 13 \text { Tahun } 2016\end{array}$ & $2016-2026$ & 2016 & $\begin{array}{l}2012 \\
\text { Tidak ada }\end{array}$ & $\begin{array}{l}2016 \\
\text { Ada, Pariwisata, pendidikan } \\
\text { kesehatan }\end{array}$ \\
\hline
\end{tabular}




\section{SIMPULAN}

Rasio Legis Lingkup Kepariwisataan diatur melalui Rencana Induk Pembangunan Pariwisata oleh daerah. Hal tersebut tidak hanya didukung oleh kewenangan Otonomi berdasarkan UU 23/2014 tentang Pemerintah Daerah beserta UU 10/2009 tentang Kepariwisataan. Akan tetapi juga didasarkan pada potensi kepariwisataan di daerah yang mampu mendukung pembangunan pariwisata nasional. Selain itu, terjadi disharmonisasi periode pemberlakuan Rencana Induk Pembangunan Kepariwisataan berdasarkan 2 (dua) sudut pandang teori. Pertama, dalam teori sinkronisasiharmonisasi, lebihnya periode RIPPARDA tidak dibenarkan dan didukung Undang-Undang Pemerintah Daerah, Undang-Undang Kepariwisataan, dan Undang-Undang Pembentukan Peraturan Daerah. Kedua, berdasarkan sudut pandang pembangunan hukum, kelebihan periode tersebut merupakan hal yang berpotensi dibenarkan dengan dalih efesiensi dan keselarasan antara pemangku kepentingan.

\section{DAFTAR PUSTAKA}

\section{Buku}

Asshiddiqie, Jimly. Pengantar Ilmu Hukum Tata Negara. Sekretariat Jenderal dan Kepaniteraan Mahkamah Konstitusi Republik Indonesia. Jakarta Pusat: 2006, hlm. 27

Hantoro, Novianto M, Sinkronisasi dan Harmonisasi Pengaturan Mengenai Peraturan Daerah, Serta Uji Materi Peraturan Daerah Provinsi Bali Nomor 16 Tahun 2009 tentang Rencana Tata Ruang Wilayah Provinsi Bali Tahun 2009-2029, Jakarta: P3DI Setjen DPR Republik Indonesia dan Azza Grafika, 2012, hlm. 9

Ibrahim, Johnny, Teori dan Metodologi Penelitian Hukum Normatif, (Malang:Bayumedia, 2007), hlm 391.

Marzuki, Peter Mahmud. Penelitian Hukum. Jakarta: Kencana, Cet. 11, 2011.

Shidarta. Karakteristik Penalaran Hukum Dalam Konteks Ke-Indonesiaan. Jakarta: Penerbit CV Utomo, 2006.
Sumiarni, Endang. Metodologi Penelitian Hukum dan Statistik. Yogyakarta: UAJY Press, 2013, hlm.5.

\section{Jurnal}

Bahiyah, Choridotul dan Wahyu Hidayat dkk. Strategi Pengembangan Potensi Pariwisata di Pantai Duta Kabupaten Probolinggo. Jurnal Ilmu Ekonomi, 2, 2018.

Hamid, Abdul. Otonomi Daerah dan Kualitas Pelayanan Publik. Academica, Februari, 2011, hlm .537.

Jahidin, H. Jumahari. Fungsi dan Wewenang Dewan Perwakilan Rakyat Daerah Provinsi Berdasarkan Asas Otonomi Daerah Seluas-Luasnya. Law Review, November, 2019, hlm.207.

Lelu, Victoria dan Mochammad Tommy Putra Perdana dkk. Strategi Peningkatan Kinerja Sektor Pariwisata Indonesia Pada Asean Economic Community. Jurnal Bisnis Dan Manajemen. Volume 8, Nomor 2, 2018.

Oka, I Made Darma. Potensi Pengembangan Pariwisata Minat Khusus (Trekking) di Desa Pejaten-Tabanan, Analisis Pariwisiata, Volume 10, Nomor 1, 2020, hlm. 25.

Rochim, Risky Dian Novita Rahayu. Harmonisasi Norma-Norma dalam Peraturan Perundang-Undangan tentang Kebebasan Hakim. Jurnal Ilmiah. Malang: Universitas Brawijaya, 2014, hlm. 7.

Setianingsih, Budhi dan Endah Setyowati dkk. Efektivitas Sistem Perencanaan Pembangunan Daerah (SIMRENDA). Jurnal Administrasi Publik (JAP), Vol.3, Nomor 11.

Sofyan dan Any Ariani Noor dkk. Industrial Research Workshop and National Seminar. Vol 7, 2016.

Tesis

Suhartono. Harmonisasi Peraturan Perundang-Undangan Dalam Pelaksanaan Anggaran Belanja Negara (Solusi Penyerapan Anggaran Belanja Negara yang Efisien, Efektif Dan Akuntabel). Tesis. Jakarta: Universitas Indonesia, 2011.

Sayuna, Inche. Harmonisasi dan Sinkronisasi Hukum Surat Kuasa Membebankan Hak Tanggungan (SKMHT) Ditinjau Dari Otentisitas Akta Menurut UndangUndang Nomor 2 Tahun 2014 tentang Perubahan Atas Undang-Undang Nomor 30 Tahun 2004 tentang Jabatan 
Notaris. Tesis. Surakarta: Universitas Sebelas Maret, 2016.

\section{Internet}

Mulyadi, Teori Hukum Pembangunan Prof. Dr. Mochtar Kusumaatmadja, Sebuah Kajian Deskriftif Analitis, dapat diakses di

https://badilum.mahkamahagung.go.id/u pload_file/img/article/doc/kajian_deskri ptif_analitis_teori_hukum_pembanguna n.pdf, diakses pada 19 Juni, 2020.

\section{Lain-Lain}

Badan Pusat Statistik. Statistik Kunjungan Wisatawan Mancanegara International Visitor Arrivals Statistics 2018. Katalog BPS:8401011, 2018, hlm 9.

Kementerian Pariwisata Bekerjasama dengan Lembaga Penyelidikan Ekonomi dan Masyarakat Fakultas Ekonomi dan Bisnis Universitas Indonesia. Laporan Akhir Kajian Dampak Sektor Pariwisata Terhadap Perekonomian Indonesia. 2018, hlm.3.

\section{Peraturan Perundang-Undangan}

Undang-Undang Dasar Negara Republik Indonesia 1945.

Undang-Undang Nomor 10 Tahun 2009 tentang Kepariwisataan, Lembaran Negara Republik Indonesia Tahun 2009
Nomor 11, Tambahan Lembaran Negara Republik Indonesia Nomor 4966.

Undang-Undang Nomor 23 Tahun 2014 tentang Pemerintahan Daerah, Lembaran Negara Republik Indonesia Tahun 2014 Nomor 244, Tambahan Lembaran Negara Republik Indonesia Nomor 5587.

Undang-Undang Nomor 17 Tahun 2007 tentang Rencana Pembangunan Jangka Panjang Nasional Tahun 2005-2025, Lembaran Negara Republik Indonesia Tahun 2007 Nomor 33, Tambahan Lembaran Negara Republik Indonesia Nomor 4700.

Peraturan Pemerintah Nomor 50 Tahun 2011 tentang Rencana Induk Pembangunan Kepariwisataan Nasional Tahun 20102025, Lembaran Negara Republik Indonesia Tahun 2011 Nomor 125, Tambahan Lembaran Negara Republik Indonesia Nomor 5262.

Peraturan Menteri Pariwisata Republik Indonesia Nomor 10 Tahun 2016 tentang Pedoman Penyusunan Rencana Induk Pembangunan Kepariwisataan Provinsi Dan Kabupaten/Kota, Lembaran Negara Republik Indonesia tahun 2015 nomor 1173. 